\title{
MEASUREMENT OF FINANCIAL PERFORMANCE IN ADOPTION OF THE ROGOTRUNNING VILLAGE BUDGET YEAR 2015 - 2018
}

\author{
${ }^{123}$ Dhayu Eka Septian, Supartini, Fetri Setyo Liyundira \\ Departement of Accountinng, STIE Widya Gama Lumajang ${ }^{13}$ \\ Universitas Merdeka Surabaya ${ }^{2}$ \\ Email: dhayuekaseptian876@gmail.com
}

\section{A R T I C LE INFO}

Date of entry:

10 January 2020

Revision Date:

12 February 2020

Date Received:

1 June 2020

\begin{abstract}
A B S T R A C T
This study aims to determine the financial performance in the absorption of Rogotrunan Urban Budget and the 2015-2018 Budget Year period. This research includes quantitative descriptive research. The analytical method used in this study is the method of Shopping Growth Analysis and Shopping Variance Analysis. The results of this study indicate that the Financial Performance of Rogotrunan Urban Village in 2015-2018 can be considered Good because the absorption rate of the budget does not exceed the highest limit in absorbing the budget, in this case the absorption of the budget in Jogoyudan village refers to the Budget and Activity Plan, and allocating expenditure that is balanced and in accordance with the need is a very important thing in the preparation of the budget and in the absorption of the budget should refer to the Budget Work Plan is not permitted to set the standard prices that have been prepared so that the financial performance in the absorption of the budget can be considered good.
\end{abstract}

Keywords: Financial Performance, Growth In Goverment Spending, Varians

Cite this as: Eka Septian, Dhayu., WImbo Wiyono, M., Setyp Liyundira, Fetri. (2020). MEASUREMENT OF FINANCIAL PERFORMANCE IN ADOPTION OF THE ROGOTRUNNING VILLAGE BUDGET YEAR 2015 - 2018. Assets : Jurnal Ilmiah Ilmu Akuntansi, Keuangan dan Pajak, 4(2), 50-56

\section{INTRODUCTION}

The local government of Lumajang district is currently demanding an optimal performance increase in budget absorption. Local government as a public bureaucracy that is responsible for improving public welfare, effectively and efficiently so that it can take the form of good governance.

This condition of the Lumajang district government encourages the need for financial and budget management so that budget allocation is more oriented towards the interests of outsiders through performance-based budgets.

The problem of low budget absorption in the first three months and ballooning in the fourth trimester is still happening today. Such budget absorption performance will not have a positive impact on the nation's development process. The absorption of the state budget requires a balance and proportion of movements that run in a sustainable manner. The goals to be achieved then are 
not only fixated on the absorption of the budget, but more importantly how the absorption of the budget can produce quality output. Based on this background, the authors conducted a study entitled "Measurement of Financial Performance in the Budget Absorption of Rogotrunan Village in 2015-2018".

\section{METHODS}

Descriptive research is conducted to describe a symptom, event, and incident that occurs factually, systematically, and accurately. In this research, the writer tries to describe the events that are the center of research without giving privileges to these events. Sugiyono (2018) states that descriptive research is research conducted to obtain the value of the independent variable, either one or more (independent) variables without making comparisons or connecting with other variables. Ibrahim (2001) states that the definition of quantitative research is research that refers to opinions, then variables are determined, and then analyzed using valid research analysis tools, especially in quantitative research.

\section{RESULTS AND DISCUSSION}

Results of Data Analysis

After the data is collected and classified, the next step is to analyze the data, namely by grouping or classifying the data and doing calculations using the Expenditure Growth Analysis and Expenditure Variance Analysis then obtaining the calculation results with the following results:

In general, spending has a tendency to always increase, according to Mahmudi (2010: 160) which states that expenditure realization has a tendency to always increase every year, the reasons for the increase in expenditure realization can be related to inflation, changes in the rupiah exchange rate, and adjustments to economic factors and conditions. others that allow support for increased spending realization. Expenditure growth must be followed by balanced income growth so that not only output stands out but must be supported by balanced inputs.

The researchers analyzed the Rogotrunan Village Budget Realization Report from 2015 to 2018. In 2015 , the growth value of Rogotrunan Village's expenditure was $11.53 \%$, which means that the performance of Rogotrunan Village in budget absorption can be considered good because according to the criteria put forward by Mahmudi (2010: 160) that if the growth value appears positive, it can be said to have increased spending growth from the year previously this condition had to be balanced with the quality in budget absorption.

Table 1. Analysis of Expenditure Growth in Rogotrunan Village

\begin{tabular}{ccccc}
\hline Year & \multicolumn{2}{c}{ Budget } & \multicolumn{2}{c}{ Budget Realization } \\
\hline 2015 & Rp & 863.612 .599 & Rp 840.146 .941 & $11,53 \%$ \\
2016 & Rp & 1.047 .473 .015 & Rp 1.042 .422 .504 & $24,01 \%$ \\
2017 & Rp & 492.000 .000 & Rp 482.571 .800 & $-53,70 \%$ \\
2018 & Rp & 759.456 .000 & Rp 746.247 .584 & $54,63 \%$ \\
\hline
\end{tabular}

Source: processed by researchers

In 2016 the value of the Rogotrunan Urban Village Expenditure Growth value increased from the previous year of $24.01 \%$ this was supported by an increase in the budget from the previous year so that the value of the Rogotrunan Village Expenditure Growth value increased. Then for 2017, it 
turned out that the Rogotrunan Urban Village Expenditure Growth decreased by $53.70 \%$ which was caused by a decrease in the Rogotrunan Urban Village budget ceiling from the previous year. But in 2018 the Rogotrunan Urban Village experienced a significant increase again of 53.63\% from the previous year which was caused by an additional budget of approximately $50 \%$ from the previous year so that in 2018 a positive value appeared in the calculation of the analysis of the growth in the expenditure growth of the Rogotrunan Village.

In 2015, the Rogotrunan Village had a Budget ceiling of IDR 863,612,599 and realized the absorption of the Expenditure Budget of IDR 840,146,941 after being analyzed using the Spending Growth Analysis technique, the researchers found that in 2015, the Rogotrunan Village experienced an increase in spending growth of $11.53 \%$. obtained because the Rogotrunan Village received an additional budget ceiling from the previous year so that the value of its spending growth had increased and in 2016 the Rogotrunan Village had a budget ceiling of Rp. $1,047,473,015$ and realized expenditure of IDR 1,042,422,504 due to an increase in the budget ceiling from the previous year, the growth in expenditure in 2016 increased by $24.01 \%$ from the previous year then in 2017 the budget ceiling for the Rogotrunan Village was IDR 492,000,000 and realized absorption. expenditure of Rp. 482,571,800 after being analyzed using the Analysis of Expenditure Growth of the Rogotrunan Village, experienced a decline in spending growth of $53.70 \%$ because the 2017 budget ceiling fell by Rp. 555,473,015 from the previous year, this is very important because it becomes the focal point for the Kelurahan In the future, Rogotrunan will be better at preparing the expenditure budgeting. For 2018, the budget ceiling for Rogotrunan Village was IDR 759,456,000 and the realization of spending was IDR 746,247,584, an increase of $54.63 \%$ due to an additional budget of IDR 267,456,000 from the previous year.

The financial performance of the Rogotrunan Village in the 2018 Fiscal Year has increased, especially in the purchase of goods and services because in 2018 the purchase of goods and services increased by Rp. 251,432,000. So for the whole year the financial performance of Rogotrunan Village can be said to be Good according to the criteria put forward by Mahmudi (2010: 160)

\section{Shopping Variance Analysis}

To find out whether the expenditure absorption does not exceed the budget ceiling, it can be obtained from the analysis of spending variance, so that researchers can find out whether the performance of the Rogotrunan Village is good or still needs improvement and guidance, calculating the value of Budget Realization Variance can be used the following formula:

Expenditure Variance $=$ Expenditure Realization - Expenditure Budget

To determine the variance value, the following criteria are used:

1. If there is an excess (direct expenditure realization exceeds the amount concerned) it is said that the direct expenditure realization has good criteria,

2. If there is a deficiency (direct expenditure realization is less than the budgeted amount) then direct expenditure financial management is considered good

Table 2. Analysis of Expenditure Variance of Rogotrunan Village

\begin{tabular}{cccccc}
\hline Year & Budget & Budget Realization & Varians & Performance \\
\hline 2015 & Rp & 863.612 .599 & Rp 840.146 .941 & Rp 23.465.658 & Baik \\
\hline 2016 & Rp 1.047 .473 .015 & Rp 1.042 .422 .504 & Rp 5.050.511 & Baik \\
\hline 2017 & $R p$ & 492.000 .000 & Rp 482.571 .800 & Rp 9.428.200 & Baik \\
\hline 2018 & $R p$ & 759.456 .000 & Rp 746.247 .584 & Rp 13.208.416 & Baik \\
\hline
\end{tabular}


Source: processed by researchers

In 2015, the value of the Rogotrunan Urban Village Expenditure variance was below the budget ceiling of Rp. 23,465,658 and it can be said to be good because according to the criteria stated by Mahmudi (2010: 159) if the variance value is below / does not exceed the budget ceiling, it can be said that budget absorption is good but if the variance value is above the budget ceiling, it can be said to be not good. Then for 2016, the annual average variance value in Rogotrunan Village does not exceed the nominal budget ceiling, as in 2015 the variance value was Rp. 5,050,511.

Likewise, in 2017, Rogtrunan Village was considered stable / Good in budget absorption because the variance value did not exceed the budget ceiling each year. In 2017 the variance value of Jogoyudan Village was Rp. 9,428,200. In 2018 the variance value of the Rogotrunan Village was obtained from the difference in the budget ceiling of IDR 759,456,000 and the realization of the budget of IDR 746,247,584 so that the variance value of IDR 13,208,416 was obtained and can be considered good because the absorption does not exceed the nominal budget ceiling.

From the comparison of Budget and Expenditure Realization in Rogotrunan Village as seen in the table above, it can be seen that there is a difference between the expenditure realization and the existing budget ceiling. In 2015 the variance value of Rogotrunan Urban Village was IDR $23,465,658$, in 2016 the variance value was IDR 5,050,511 and in 2017 the variance value was IDR 9,428,200 as well as in 2018 the variance value was IDR 13,208,416. In general, when viewed from the difference between the realization of expenditure and the expenditure budget, it is very possible that there is a weakness and budget planning so that the estimates in the expenditure are inaccurate and it may be that the budget is not absorbed, there are programs or activities that are not implemented and channeled to expenditure posts that still need or less. But in essence the financial performance of Rogotrunan Village is considered good because normatively the expenditure budget is the highest limit in expenditures that can be made.

Discussion of Research Results

Based on the results of the above data analysis using the calculation of the Expenditure Growth analysis and the Shopping Variance Analysis, it can be described as follows:

Expenditure Growth Analysis

The level of spending growth is measured according to the criteria for evaluating the performance of spending growth if it is positive, then the realization of the direct expenditure budget has increased, whereas if it is negative, it will experience a decrease in expenditure growth. Mahmudi (2010: 160) states that expenditure realization has a tendency to always increase every year, the reason is the increase in expenditure realization can be linked to inflation, changes in the rupiah exchange rate, and adjustments to economic factors. Expenditure growth must be followed by balanced income growth. Based on the analysis that has been done, it can be explained that the growth rate of the Rogotrunan Urban Village expenditure in 2015-2016 can be said to be good

The growth value of Rogotrunan Village's expenditure in 2015 Realization of the previous year amounted to IDR 753,273,530 and the 2015 Realization was IDR 840,146,941 and an increase in expenditure growth of Rogotrunan Village was obtained by $11.53 \%$. Previously so that an increase in expenditure growth could be obtained in 2015, for 2016 the realization of the previous year was IDR 840,146,941 and the realization of expenditure in 2016 was IDR 1,042,422,504 and an increase in the absorption of expenditure in the Rogotrunan Village was $24.01 \%$ from the previous year. This was supported by an increase in the budget ceiling from the previous year, and in 2017 the realization of the previous year's budget absorption was Rp. 1,042,422,504 and the realization in 2017 was Rp. -53.70\% this is necessary It is noted that in the preparation of budget planning more attention is paid so that budget absorption does not decrease from the previous year, likewise for 2018 the realization of the previous year was IDR 482,571,800 and in 2018 the realization of budget absorption was IDR 746,247,584 due to the Regent's policy at that time, Rogotrunan 
Village experienced an increase again significantly by $53.63 \%$ from the previous year which was caused by an additional budget of approximately $50 \%$ from the previous year, so for financial performance in the absorption of the 2018 Rogotrunan Village budget, it can be said to be good according to the existing criteria

The essence of this expenditure growth analysis is more about how the budget absorption value is in a positive position so that financial performance can be said to be good and if the value of expenditure growth appears in a negative position, it can be said that the financial performance in budget absorption is not good and needs to be corrected for the upcoming fiscal year. If each year gets a Good value, it is likely that the next year's budget ceiling will be given an addition and can be assessed as Good performance because it is right in the use of the budget

\section{Shopping Variance Analysis}

Mahmudi (2010: 157) states that the expenditure variant is the difference between the expenditure realization and the expenditure budget and can be used to measure the level of difference. Budget differences can be divided into two, namely the difference between favorable and unfavorable. The expenditure variance between the expenditure budget and its realization can be said in terms of nominal or percentage. Favorable variance is when the expenditure realization is less than the expenditure budget, whereas on the contrary the realization is greater than the budget ceiling, it is said to be unfavorable variance. Budget performance assessment generally uses variance or difference analysis, because this analysis can determine the efficiency carried out by the Regional Government. From the data results based on the assessment criteria described by Mahmudi (2010: 159), the Rogotrunan Village during 2015-2018 was considered Good. This is because the direct expenditure budget does not exceed its budget.

In 2015 the budget ceiling for Rogotrunan Village was Rp. 863,612,599 and the absorption or realization of the Expenditure Budget was Rp. 840,146,941 from the nominal data of the 2015 budget ceiling and budget absorption, it can be obtained that the variance value of Rogortunan Village expenditure is Rp. 23,465,658 can be said to be good financial performance because the variance value in 2015 is in a position below the nominal budget ceiling of the Rogotrunan Village, for 2016 the nominal budget ceiling of the Rogotrunan Village is IDR 1,047,473,015 and the budget absorption is IDR 1,042,422,504 so that a variance value of IDR 5,050,511 can be obtained and it can be said to be good because the variance value shows a positive value and is in a position below the 2016 budget ceiling. And in 2017 the Rogotrunan Village budget ceiling is IDR $492,000,000$ and the expenditure absorption is IDR 482,571,800 so that a variance value of IDR $9,428,200$ can be obtained. 2017 can be said to be good so that the variance value is in a positive position, likewise in 2018 the 2018 budget ceiling of Rp. 759,456,000 and budget absorption of Rp. 746,247,584 so in 2018 the Rogotrunan Village again experienced an increase in budget and the value of the variance in spending of the Rogotrunant Village remained in a positive position of Rp. 13,208,416.

The variance value of the realization with the budget of the Rogotrunan Urban Village as a whole shows an average of $2 \%$ of the difference in budget that was not realized for 4 years or $98 \%$ of the budget that was realized for 4 years. By looking at the Analysis of Variance so that Rogotrunan Village pays more attention to budget absorption so that the ability of the Regional Apparatus Bureaucracy is considered Good

\section{CONCLUSION}

This research used mining sector companies in 2011-2015, as many as 26 companies were sampled. Disclosure of environmental accounting is an independent variable $(\mathrm{X})$ that is measured using an appropriate rating, while stock performance is a Dependent variable (Y). And based on the results of data analysis processed in the SPSS Version 16 application, it can be concluded as follows: If a company is registered to join this program, then the company will get the right rating, there are five appropriate ratings (black, red, blue, green, and gold.) Which means a company that 
gets a black rating means that the company in dealing with postal accounting environmental post is very bad. And if the company gets the value of gold, then the company is already very worried about overcoming its posts.

\section{REFERENCE}

Sukardi. (2013). Bab Iii Metode Penelitian a. METODE PENELITIAN ILMIAH, 84, 487-492. http://ir.obihiro.ac.jp/dspace/handle/10322/3933

Purwanti, S. R. I. A., \& Pd, M. (2018). KELURAHAN KUTOANYAR KECAMATAN TULUNGAGUNG KABUPATEN TULUNGAGUNG PERIODE 2013-2017 Oleh : Dibimbing oleh: PROGRAM STUDI AKUNTANSI UNIVERSITAS NUSANTARA PGRI KEDIRI SURAT PERNYATAAN ARTIKEL SKRIPSI TAHUN2018.

Sarmiyatiningsih, A. R. D. (2010). Analisis Kinerja Keuangan Dan Pertumbuhan Ekonomi Sebelum Dan Sesudah Diberlakukannya Otonomi Daerah Di Kabupaten Kulon Progo.Jurnal Bisnis Dan Ekonomi, 1(2), 31-42.

Demora, V. (2016). Analisis derajat desentralisasi dan kemandirian PAD serta hubungannya dengan produktivitas belanja daerah di Kota Jambi.E-Jurnal Perspektif Ekonomi Dan Pembangunan Daerah, 5(1), 13-20.

Pramono, J. (2014). Analisis Rasio Keuangan Untuk Menilai Kinerja Keuangan Pemerintah Daerah. Jurnal Ilmiah Among Makarti, 7, 83-112.

Abdullah, Syukriy Nazry, R. (2015). Analisis Varian Anggaran Pemerintah Daerah Penjelasan Empiris dari Perspektif Keagenan.Jurnal Samudra Ekonomi Dan Bisnis, 6(2), 272-283.

Sukmaningrum, T. (2012). Laporan Keuangan Pemerintah Daerah ( Studi Empiris Pada Pemerintah Kabupaten dan Kota Semarang ). Skripsi Universitas Diponegoro.

Febrian Cahyo Pradono,\& Basukianto. (2015). Kualitas Laporan Keuangan Pemerintah Daerah: Faktor Yang Mempengaruhi Dan Implikasi Kebijakan (Studi Pada SKPD Pemerintah Provinsi Jawa Tengah). Jurnal Bisnis Dan Ekonomi (JBE), 22(2), 1-13.

Wantah, M. J. (2015). Analisis Penerapan Psak No.1 Tentang Penyajian Laporan Keuangan Pada Perum Bulog Divre Sulut Dan Gorontalo.Jurnal Berkala Ilmiah Efisiensi, 15(04), 74-88.

Cahyani, P., Susanti, W., Rosyafah, S., Akuntansi, P., Ekonomi, F., \& Bhayangkara, U. (2015).Analisis Penerapan Du Pont System Terhadap.Jurnal Ekonomi Akuntansi Equity, 106-117.

Sanjaya, A. R., \& Marlius, D. (2017). Peranan Laporan Keuangan Dalam Kebijaksanaan Pemberian Kredit Kepada Calon Nasabah Pada Pt. Bpr Batang Kapas. Junal Akuntansi Keungan, 12.

Akuntansi, J., \& Ratulangi, U. S. (2017). 3 1,2,3. 12(71), 149-156.

DORI SAPUTRA. (2014). Analisis Kemandirian Dan Efektivitas Keuangan Daerah Pada Kabupaten Dan Kota Di Propinsi Sumatera Barat.

Ma'ruf. 2019.Pengertian Analisis Rasio Keuangan 5 Jenis dan Rumusnya Menurut Para

Ahli.https://www.akuntansilengkap.com. Diakses tanggal 25 Januari 2020 (format salah)

Wahyu Lusiana, F. (2010). Analisis Pengaruh Rasio Likuiditas, Rasio Solvabilitas, Rasio Aktivitas, Dan Rasio Profitabilitas Terhadap Price Earning Ratio Pada Perusahaan Manufaktur Yang Terdaftar Di Bursa Efek Indonesia. Jurnal Manajemen, 2(3), 13-21.

Susantih, H., \& Saftiana, Y. (2008).Perbandingan Indikator Kinerja Keuangan Pemerintah Propinsi Se-Sumatera Bagian Selatan.Program Pasca Sarjana Universitas Sriwijaya.

Sijabat, M. Y., Saleh, C., \& Wachid, A. (2012).Analisis Kinerja Keuangan serta Kemampuan Keuangan Pemerintah Daerah dalam Pelaksanaan Otonomi Daerah.Administrasi Publik $(J A P)$ 2(32),

236-242. http://administrasipublik.studentjournal.ub.ac.id/index.php/jap/article/view/365

Lumingkewas, V. A. (2013). Pengakuan Pendapatan dan Beban Atas Laporan Keuangan Pada PT. Bank Sulut.Journal of Chemical Information and Modeling, 53(9), 1689-1699. https://doi.org/10.1017/CBO9781107415324.004 
Kainde, C. (2013). Analisis Varians Dan Pertumbuhan Belanja Daerah Pada Pemerintah Kota Bitung.Emba, 1(3), 393-400.

Karinda, C. Y., Ilat, V., \& Mawikere, L. (2013).Analisis Kinerja Anggaran Belanja Pada Badan Pengelola Keuangan Dan Barang Milik Daerah Provinsi Sulawesi Utara.Accountability, 2(2), 73. https://doi.org/10.32400/ja.3689.2.2.2013.73-84

Cahyani, P., Susanti, W., Rosyafah, S., Akuntansi, P., Ekonomi, F., \& Bhayangkara, U. (2015).Analisis Penerapan Du Pont System Terhadap.Jurnal Ekonomi Akuntansi Equity, 106-117.

Sukardi. (2013). Bab Iii Metode Penelitian a. METODE PENELITIAN ILMIAH, 84, 487-492. http://ir.obihiro.ac.jp/dspace/handle/10322/3933 